Preliminary draft - do not cite without permission

\title{
Immigrants and the Spatial Mismatch Hypothesis: Employment Outcomes among Immigrant Youth in Los Angeles
}

\author{
by \\ Cathy Yang Liu \\ liuyang@usc.edu \\ Gary Painter \\ gpainter@usc.edu \\ Duan Zhuang \\ dzhuang@usc.edu
}

School of Policy, Planning and Development

University of Southern California

Los Angeles, CA 90089-0626

\begin{abstract}
This paper examines the effect of space and race/ethnicity on labor force participation outcomes among minority and immigrant youth in the Los Angeles metropolitan areas. This research contributes to the spatial mismatch literature by analyzing the differences between first and second generation immigrants in addition to exploring the role of race and job accessibility on the likelihood of working. It does so by comparing the employment status of comparable youth (16-21) who reside in central cities, inner ring suburbs and outer ring suburbs respectively using 2000 Census PUMS data. Finally, we model the decision to attend school and to work in a bivariate probit framework to discover how the correlation across decision may change the estimated impact of race and space on employment. The results of this study suggest that both space and race play a role in probability that a youth will work, but that the decision to attend school does not impact influence the estimated impact of space and race on employment.
\end{abstract}




\section{INTRODUCTION}

Much attention in both the academic and popular press has been focused on the problems of urban poverty and on the suburbanization of the population and jobs in urban areas. These phenomena were first linked together by John Kain (1968) to explain high minority unemployment in central cities of metropolitan areas. Since Kain's seminal work, a number of authors (Kain, 1992; Ihlanfeldt and Sjoquist 1998; Preston and McLafferty 1999 provide reviews) have tested for the presence of the spatial mismatch hypothesis using a variety of different outcome measures such as job accessibility, wages, and commute times to test directly for mismatch, and more recently authors have tested for a geographic mismatch in skills (e.g., Stoll 2005) between the jobs that are nearby and the skills that local residents possess. While most studies have found evidence of mismatch in either space or skills, a few studies (e.g. Ellwood 1986, Gordon et al 1989, Taylor and Ong 1995) find that no mismatch exists, while still others (Jencks and Mayer 1990) criticize the work of the proponents of the spatial mismatch hypothesis because most studies do not fully account for the endogeneity of location choice. ${ }^{1}$

Despite the voluminous literature on the spatial mismatch hypothesis, there is very little literature on the importance of the spatial mismatch between job growth and population growth for Latinos, Asians, and immigrant households. Ihlanfeldt (1993) conducted one of the first studies of the spatial mismatch hypothesis among Latino youth, and found that approximately one fourth of the job differential between whites and Latinos is due to living further from jobs. Unfortunately, this study did not distinguish between native and foreign-born households who may be differentially affected. Some

\footnotetext{
${ }^{1}$ Ross (1998) is a notable exception which explicitly models residential and job location choices simultaneous.
} 
recent studies have started to explore the validity of the spatial mismatch hypothesis for immigrant populations, but with mixed results (e.g. Aponte 1996, Preston et al 1998, Pastor and Marcelli 2000, Parks 2004a and 2004b).

Because demographers (Frey 2002) have documented the fact that immigration is the primary force shaping metropolitan areas, it is important to determine the role of urban spatial structure on the economic outcomes of immigrants, and to compare immigrant populations and their children to the outcomes of native-born residents of urban central cities. Theoretically, the expectation about how immigrants and their children may be affected by spatial mismatch is ambiguous. Because new immigrants are likely to reside in ethnic enclaves (e.g., Wilson and Portes 1980), this concentration may disadvantage them as job growth happens in the suburbs. This may be exasperated by the fact that immigrants are more likely to lack English skills. On the other hand, immigrants may be a more mobile population (Painter et al 2001), and therefore able to follow the jobs where they move (Borjas 2001).

In this study, we investigate the extent to which spatial mismatch between population growth and job growth affects youths aged 16-21 in the Los Angeles Metropolitan Area. Following Ellwood (1986) and Raphael (1998a), we focus on youth because their location is assumed to be exogenously determined by their parents. In this analysis, we separate the urban geography into three areas - the central city, the inner ring suburbs, and the outer ring suburbs (see Stoll 1999c for similar geographic partition for Washington D.C. area and Pastor 2001, McConville and Ong 2003 for Los Angeles). The new focus on the inner ring suburbs is important because many urban problems as were traditionally associated with central cities - deteriorated infrastructure and old 
housing stock, high crime rates, low-quality public schools, and concentration of minority and poor households - are quickly spreading to inner ring suburbs.

In addition to measuring the impact of space on various native populations, we focus on both immigrant youths and the children of immigrants to investigate how immigrants are affected by potential spatial mismatch as past literature has suggested that these two groups may register somewhat different economic mobility trajectories (Portes and Zhou 1993). Finally, we contribute to the literature by simultaneously modeling the decision to work and the decision to go to school in order to account for the possibility that youths in the age range may choose to go to school instead of work or do both.

\section{BACKGROUND AND LITERATURE REVIEW}

\section{$\underline{\text { Spatial Mismatch Hypothesis }}$}

Changing urban structure and social relations in the later half of the twentieth century prompted the exploration of the linkage between space and race in explaining inter-group labor market differentials. The "Spatial Mismatch hypothesis" (SMH) was first introduced by Kain (1968) to suggest a spatial explanation to the inferior employment outcome of inner city minorities. The hypothesis states that there is a divergence between the concentration of minority workers in the inner cities and the fast suburbanization of employment that hinder their employment opportunities. Inner city minorities are not able to move to where the growth in jobs is occurring due to their residential location constraints imposed by housing market discrimination. Holzer (1991), Kain (1992), Ihlanfeldt and Sjoquist (1998), and Preston and McLafferty (1999) all provide comprehensive and critical review of this empirical literature. 
There exist numerous methodological approaches and measures to test the spatial mismatch hypothesis and evidence in support of this hypothesis has been somewhat mixed. ${ }^{2}$ Some of the dependent variables used to gauge the existence of spatial mismatch include (1) racial comparisons of commuting times or distances; (2) correlations of wages and the employment rate with measures of job accessibility and (3) comparisons of the labor market outcomes of central city and suburban residents (Ihlanfeldt and Sjoquist 1998, p.852).

While embedded in the general term of "space", various research emphasize s different facets and causes of inner city minorities' labor market difficulties. Early challenges to SMH use macro-level aggregate statistics and find that blacks do not fare significantly better even if they are closer to job opportunities and that race, rather than space, constitutes the main barrier to their labor market success (e.g. Ellwood 1986). Some employ commute data to test $\mathrm{SMH}$ and reject the hypothesis based on the fact that minority workers have very similar commuting distance with white workers (e.g. Gordon et al 1989) and that minority's longer commute time is explained by their heavier dependence on slower public transit - "auto mismatch" (Taylor and Ong 1995), or “transportation mismatch" (Ong and Miller 2005), defined as accessibility to automobiles, rather than spatial mismatch is the determining factor of central city residents' poor labor market outcomes. Raphael and Stoll (2001)'s study indicate that boosting minority carownership to that of the white can narrow inter-racial employment rate differentials to a large extent (45\% of black-white employment rate gap and $17 \%$ for Latino-white gap).

\footnotetext{
2 Ihlanfeldt and Sjoquist (1998) concluded that 21 of 28 new studies that were produced between 1992 and 1998 on SMH that they reviewed show at least moderate support for the hypothesis.
} 
At the same time, the majority of the literature examines intra-metropolitan employment outcome differentials among different racial/ethnic groups (Ihlanfeldt and Sjoquist 1990, Stoll 1999a, 1999c, Raphael 1998b) and establishes that spatial residential location and job accessibility's significant effect on the unfavorable labor market outcomes of minorities as compared to whites. One empirical challenge to these types of studies is that the simultaneity of an individual (and the household)'s location choice and employment decision is not accounted for properly. In an effort to bypass this endogeneity issue, researchers have restricted their sample to youth in their studies (e.g. Stoll 1999a, 1999c, Raphael 1998a, 1998b, O'Regan and Quigley 1998). The rationale behind using at-home youth sample is that the parents make the residential choice decision without concern for their children's employment in the future. ${ }^{3}$

In the literature, there also exist numerous measures of job accessibility. ${ }^{4}$ Raphael (1998a, 1998b) make the case for using net job growth over a time period instead of absolute employment level in a given locale as the appropriate measure that captures the labor market dynamics as applicable to youth. This is because that youth workers with less than a college degree are usually new to the labor market and tend to occupy the lower end of the job hierarchy. The newly created jobs, especially in such industries as manufacturing, services and retail, provide them with most accessible job opportunities. In addition, due to students' school obligations and youth's general lack of automobile access, they tend to conduct their job search within a closer proximity to home.

\footnotetext{
3 Youth's labor market behavior is also examined specifically because of their poor labor market performance and limited mobility and youth's relatively large employment differentials by race/ethnicity as compared to adults (Stoll 1999a).

${ }^{4}$ These include but are not limited to job-population ratio, total number of jobs within a given radius, and distance-decay gravity-type measures.
} 
The availability of Multi-City Survey of Urban Inequality for the four cities of Atlanta, Boston, Detroit and Los Angeles has provided researchers with new data source for SMH-related research, especially from the demand-side of employers and the job search process of workers. A series of papers by Stoll and his collaborators have explored the spatial job search pattern and quality of workers by race/ethnicity, and proposed the hypothesis of "geographical skills mismatch" between the skills requirement of jobs in workers' search area and their own skills sets (see Stoll 1999b, Stoll et al 2000, Stoll and Raphael 2000, Stoll 2005). While this paper does not look at skills in particular, as our analysis sample is composed of low-skilled youth, we do place focus on employment in different industries according to their average skills requirement as proxy for available employment opportunities for youth.

\section{Evolving Urban Geography}

While spatial mismatch hypothesis originated in the $1960 \mathrm{~s}$, the $21^{\text {st }}$ century has witnessed the continued trend of low-density suburban sprawl, decentralization and dispersion of businesses and residences and declining central cities. Vast majority of central cities all around the nation are losing jobs, especially private sector jobs, to their suburbs (Brennan 1999). Such urban problems as were traditionally associated with central cities - deteriorated infrastructure and old housing stock, high crime rates, lowquality public schools, and concentration of minority and poor households - are quickly spreading to inner ring suburbs as well (Downs 1997).

The central city - suburb boundaries are becoming increasingly difficult to define. For a polycentric urban area like Los Angeles (e.g. Giuliano and Small 1991), this spatial form may have distinctive features with respect to the concentration of poverty and 
joblessness, people's residential location, commuting and job search behaviors from what traditional mono-centric cities would imply. Accordingly, this paper goes beyond the standard central city - suburb framework adopted in most work of this kind, and to adopt a more nuanced partition of urban geography: central city, inner ring suburbs and outer ring suburbs for the five counties of Southern California (Los Angeles CMSA). The geographic division based on census PUMAs (Public Use Microdata Areas) is largely consistent with the boundary delimitations developed by Pastor (2001) and adopted by McConville and Ong (2003) ${ }^{5}$. In the spatial mismatch literature, Stoll (1999c) employed a similar partition of space in his study of the Washington, D. C. area (District of Columbia, inner-beltway, outer beltway).

As Table 1 demonstrates, the Los Angeles metropolitan area is representative of this phenomenon as both the City of Los Angeles and the inner ring suburbs in the rest of Los Angeles County lost jobs, and the outer ring suburbs gained jobs over the decade of the 1990s. This is despite population growth in both the central city and the inner ring suburbs. In both the central city and the inner ring suburbs, there were dramatic jobs contractions in the manufacturing sector (over 20\%) and service sector $(25.3 \%$ and $5.7 \%$ respectively). ${ }^{6}$ This is important because these are the two sectors that are most likely to employ the low-skilled workers. Unlike the regions within the county of Los Angeles, the suburbs outside of the county experience substantial growth in the service sector (a $10.2 \%$ gain) and solid growth in manufacturing (11.3\%).

\section{The Importance of Immigrants}

\footnotetext{
${ }^{5}$ They used a different terminology: "inner-city Los Angeles", "Los Angeles County suburbs", and "other suburbs".

${ }^{6}$ The industry groupings are discussed below in the data section.
} 
Recent population trends in the United States indicate that growth of the foreignborn population and continued arrival of new immigrants will constitute a substantial source of the country's population growth over the decades. The foreign-born population grew by more than $50 \%$ between 1990 and 2000, and in the year 2000, there were 31.1 million immigrants, or 12.1 million foreign-born households in the United States (Myers and Liu 2005). This is especially true for gateway metropolitan areas. While it is estimated that the new inflow of immigrants to California is leveling off, the children immigrants (or second-generation immigrants) will be entering the labor force at an unprecedented level than ever before (for a detailed demographic projection, see Myers et al 2005). The spatial distribution of immigrant youth in the labor market and how they match the employment growth patterns in the U.S. economy will be an important area of investigation in the future.

Despite its present and future significance, immigrants' labor market experiences are not adequately addressed in the SMH debate. Various literatures have demonstrated that immigrants' economic mobility trajectories are somewhat different from those of whites and other native born minorities in both the urban housing market (e.g., Painter, Gabriel and Myers 2001) and the urban labor market (e.g., Ellis and Wright 1999). However, it is indeterminate how space plays out in the urban context in immigrants' employment outcomes. On the one hand, it is assumed that immigrants, as new minorities, face the same geographic barriers as traditional central city residents, while on the other hand, they may not be as affected by basic tenants of the SMH as they are residentially more mobile, and would be able to chase job opportunities (Borjas 2001). 
How social and spatial factors confound each other and play out in immigrant youth's employment outcomes remains an open question. On the one hand, some researchers find that immigrants are not as constrained by spatial effects in the labor markets. Immigrants (especially Mexican) workers consistently depict relatively high employment rate as compared to native-born minority workers, which might be attributable to their strong social networks in job search and employers' hiring strategy (Aponte 1996). Pastor and Marcelli (2000) also find that individual skills matter more than "pure" spatial mismatch in Los Angeles, especially for recent Latino immigrants. While acknowledging the role of social networks in connecting immigrants to employment, they however caution about the quality of these jobs. On the other hand, Preston et al (1998)'s results indicate the persistence of spatial barriers faced by immigrant workers as evidenced by their overall longer commutes than their Americaborn counterparts in New York. Parks (2004a, 2004b) also analyzed the labor market outcomes of selected immigrant groups in the Los Angeles context, and has found that space still matters in determining less-educated workers' employment prospects.

This paper extends this research on immigrants in a number of important ways. These previous analysis have not analyzed the differential impact of job accessibility across different geographies, have used data from the 1980s, and have not separately modeled the labor market impacts of first-generation immigrants and second-generation immigrants (children with at least one foreign-born parent). This later distinction is important in the assimilation literature as theory suggest that these groups go through diverse paths of acculturation into the U.S. economy and society (Zhou 1997; Zhou 2001). 


\section{DATA AND METHODOLOGY}

$\underline{\text { Data }}$

The primary dataset for this study will be decennial 2000 census 5\% Public Use Microdata Sample (PUMS) files for Los Angeles Consolidated Metropolitan Area (CMSA). ${ }^{7}$ The PUMS data is commonly used in the analysis of the spatial mismatch hypothesis because it offers a very detailed list of household and individual level data, and also provides important geographic identifiers. The Los Angeles CMSA is a very diverse metropolitan area both economically and racially. It is home to a large number of racial/ethnic minorities and immigrants, which offers sufficient size to estimate models across racial and immigrant group.

The PUMS data are merged with census tract level employment data for 1990 and 2000 from the Southern California Association of Governments (SCAG). The employment data are developed by SCAG from wage and compensation data reported to the State Economic Development Department (EDD) of the California Labor and Workforce Development Agency. ${ }^{8}$ Because the US Census changes tract boundaries for every census cycle, we chose 2000 census tracts as our unit of analysis, and converted all the 1990 data to 2000 census tract geography. In doing so, we used correspondence tables between 1990 and 2000 census tracts provided by SCAG. ${ }^{9}$ There are 3,373 tracts covering a total area of about 20 million acres for the whole Los Angeles five-county region.

\footnotetext{
7 The Los Angeles CMSA includes Los Angeles County, Orange County, Riverside County, San Bernardino County, and Ventura County, see Figure 1, Figure 2.

${ }^{8} \mathrm{See}$ http://www.calmis.ca.gov/file/resource/indmeth.htm for more information. EDD data is based on a random survey of employers. It includes all jobs subject to wage (tax) reporting and excludes selfemployment and private household workers.

${ }^{9}$ Correspondence tables contain multiplication factors to transfer data between two comparable geographies such as 1990 census tracts and 2000 census tracts.
} 
Because our sample of youths is derived from the PUMS, we had to transform census tract level employment into PUMA level employment. We used the 2000 Census - PUMA correlation tables for this transformation. ${ }^{10}$ In the first step, we used the SCAG 1990-to-2000 census tract correspondence table to allocate 1990 employment to 2000 census tracts. Next we applied the 2000 census - PUMA correlation table to summarize employment by 2000 PUMA for both 1990 and 2000 employment. The 3,373 tracts were converted to 1102000 PUMAs. Although the SCAG employment data include employment by one-digit SIC code, we combined agriculture with construction and mining, retail with wholesale, and transportation with utilities and public administration. ${ }^{11}$ This combination results in six major industrial sectors for our analysis for both 1990 and 2000. As was noted in Table 1, total employment and employment in manufacturing, services, and in the agriculture, mining and construction industries fell in both the central city and inner-ring suburbs during the decade of the 1990s, while all employment in all sectors grew in the outer ring suburbs. These growth rates in the six industry groupings are then included as explanatory variables in the regression models.

\section{$\underline{\text { Empirical Model }}$}

The sample for this research will be all at-home youth between the ages of 16 and 21 who have no post-high school degrees and no work-preventing physical disabilities. Following the basic methodology of Raphael (1998a), this paper will focus on the roles of space, race and socioeconomic characteristics of youth. The initial regression models are estimated in a probit framework and are of the form:

\footnotetext{
${ }^{10}$ See http://oseda.missouri.edu/plue/ for details.

${ }^{11}$ SIC refers to Standard Industrial Classification. The one-digit level classification includes ten sectors: agriculture, mining, construction, manufacturing, wholesale, retail, FIRE, service, transportation and utilities, and public administration.
} 


$$
\boldsymbol{E}=f(\boldsymbol{S}, \mathbf{R}, \boldsymbol{X}) \text {. }
$$

In this model, $\boldsymbol{E}$ is binary employment status (employed or not). $\boldsymbol{S}$ represents the geographic variables - central city, inner-ring suburbs or outer-ring suburbs. $\boldsymbol{R}$ is a vector of dummy variables of race/ethnicity (Hispanic, Non-Hispanic White, Non-Hispanic Black and Non-Hispanic Asian) and immigration status $\left(1^{\text {st }}\right.$ and $2^{\text {nd }}$ generation immigrants).

$\boldsymbol{X}$ is composed of vectors of individual characteristics, family and household characteristics, and labor market characteristics that have been found to be relevant for a youth's job prospects based on the current labor market literature. Individual variables will include age, gender, and educational background. Family background variables would include number of workers in household, number of youth workers, auto ownership, education/work experiences of parents, household income and housing tenure. Finally, the labor market variables include measures of both job availability and competition in the job market. The first measure used is the number of youths in a PUMA that may compete for the jobs in that PUMA. The final measures capture the job growth in each PUMA based upon the six industry groupings discussed above (a description of the independent variables is provided in Appendix table A.1).

Next the employment models are stratified by race and immigrant status to determine the interaction between space and employment outcomes as previous research (e.g. Raphael, 1998a; Preston et al 1998) has demonstrated that there are distinct differences across race and space, but little research has investigated the differential impact of space by immigrant status. Finally, we estimate a bivariate probit model to simultaneously model a youth's likelihood that they will be in school and be employed in 
the labor market. ${ }^{12}$ Previous research that has incorporated the likelihood of attending school has typically created a variable measuring the activity level of students defined as equal to one if either the student is in school or working in the labor market. The bivariate probit framework is a more appropriate modeling approach because it allows for correlation across the equations that estimate the likelihood of working and of attending school.

Table 2 provides an initial view of the employment and schooling rates of the youth, stratified by area and race/ethnicity (and for Asian and Latino, immigrant status). Across the racial/ethnic groups, white youth have the highest employment rates, followed by Latino, Asian and Black youth. In terms of rate of going to school, however, Asian youth have the highest rates, followed by White, Latino and Black youth. Across space, youth living in the outer-ring suburbs have highest employment rate and youth living in the central city have the lowest employment rate. This pattern is consistent with the

\footnotetext{
${ }^{12}$ Bivariate probit model can be considered as a two-equation extension of the probit model, with correlated disturbances. The general specification is:

$y_{1}^{*}=\chi_{1}{ }^{\prime} \beta_{1}+\varepsilon_{1}, y_{1}=1$ if $y_{1}^{*}>0,0$ otherwise,

$y_{2}^{*}=\chi_{2}{ }^{\prime} \beta_{2}+\varepsilon_{2}, y_{2}=1$ if $y_{2}^{*}>0,0$ otherwise,

$E\left[\varepsilon_{1} \mid \chi_{1}, \chi_{2}\right]=E\left[\varepsilon_{2} \mid \chi_{1}, \chi_{2}\right]=0$,

$\operatorname{Var}\left[\varepsilon_{1} \mid \chi_{1}, \chi_{2}\right]=\operatorname{Var}\left[\varepsilon_{2} \mid \chi_{1}, \chi_{2}\right]=1$,

$\operatorname{Cov}\left[\varepsilon_{1}, \varepsilon_{2} \mid \chi_{1}, \chi_{2}\right]=\rho$.

Let $q_{i j}=2 y_{i j}-1, z_{i j}=\chi_{i j}^{\prime} \beta_{j}$ and $w_{i j}=q_{i j} z_{i j}, j=1,2$,

and $\rho i^{*}=q_{i 1} q_{i 2} \rho$.

$\operatorname{Thus} \operatorname{Prob}\left(Y_{1}=y_{i 1}, Y_{2}=y_{i 2} \mid \chi_{1}, \chi_{2}\right)=\Phi_{2}\left(w_{i 1}, w_{i 2}, \rho i^{*}\right)$,

the likelihood function is $\log L=\sum_{i=1}^{n} \ln \Phi_{2}\left(w_{i 1}, w_{i 2}, \rho i^{*}\right)$. (Adapted from Greene 2002, p. 710)

In our case, $Y_{1}$ is employment and $Y_{2}$ is enrollment in school. We regress these two dependent variables on the same set of independent variables as described earlier $\left(\mathrm{X}_{1}=\mathrm{X}_{2}\right)$ to jointly examine youth's decision to participate in the labor force and decision to go to school.
} 
employment growth trends observed in Table 1, and suggests that residential location and spatial accessibility to jobs may be affecting youth employment. Finally, Table 2 demonstrates that there is a large difference in the employment rates of Asians of different immigration status. Immigrant youth and children of immigrant parents have much lower rates of employment than do native born children of native born parents. The rates of attending school are much more similar. On the other hand, the differences in employment rates are much more muted for Latino youth across immigration status.

Table 3 and Table 4 display the mean characteristics of the individual, household and family variables by area and by race/ethnicity, respectively. Many of the characteristics are similar across space (Table 3). Exceptions include the mean income and as a consequence the poverty rate, home and car ownership, the presence of additional youth workers in the household, and the racial composition of the each area. In particular, the central cities and inner-ring suburbs are much more likely to non-white as well as much higher numbers of first and second generation, immigrant youth. The differences across race (Table 4) are consistent with past literature on urban inequality across racial groups. There are significant differences across racial groups in the household income and the educational attainment of the parents. There are also important racial differences in location, with the largest proportion of the white population most likely to locate in the outer ring suburbs, and the largest population of other racial groups most likely to locate in either the central city or the inner-ring suburbs.

\section{EMPIRICAL RESULTS}


The regression results from the probit models are presented in Table 5. Each column displays different sets of controls in order to highlight the contribution of various controls in explaining the spatial differences in employment rates. The results in Model 1 confirm the correlations evident in Table 2 in the regression framework. Namely, residence in the central city and in the inner suburbs results in a lower likelihood of employment. All of the race/ethnicity and immigrant status indicators are significant at the $.1 \%$ level. A portion of these differences is explained by individual, family and household characteristics (Model 2), as the spatial coefficient estimates on the spatial indicators fall by about a third, but they remain significant. The lowest employment probabilities are for black and Asian youth. Latino youth are also less likely to be employed than are white youth though the effect is not significant. Status as either a first or second generation immigrant youth leads to lower employment probabilities.

In the Model 3, job accessibility and labor supply variables are added. The importance of space is further lessened, but remains significant at the $.1 \%$ level. The inclusion of these additional controls has a sizeable effect on the employment probabilities of being Latino. In particular, the Latino coefficient falls to -.02. The coefficient for Asian youth and immigrant status falls less after the addition of the controls.

Most of the other individual, household, family variable coefficients are of expected signs. Age has a positive effect on employment, and higher education attainment does lead to higher employment probability, all else equal. Attending school and living in a family whose income is below the poverty level lowers the likelihood that a youth will work. Among other members of the household, having more workers and 
youth workers in a household increases the probability that a youth will work, likely due to the fact that these other working members in a household generate useful information and social networks for the youth. This finding confirms the significant role of working parents and siblings in bridging youth to the labor market (O'Regan and Quigley 1991). As others have found (Raphael and Stoll 2001), the presence of an automobile in the household extends youth's job search and working sphere to a large extent and is positively associated with youth's employment prospects. Parents' education and work experience also contribute positively to youth employment either due to increased access to employment networks or possibly due to possibly role model effects.

The impact of the job accessibility and job competition variables has the expected signs. Having a greater number of youths that live in one's own PUMA decreases the likelihood that a youth will find employment. Since this is primarily an unskilled working population, only the manufacturing and service job growth variables are statistically significant.

Overall, this evidence is supportive of the spatial mismatch hypothesis - living in the central city and in the inner-ring suburbs jeopardizes youth's employment probabilities and controlling other explanatory variables does not eliminate this effect. In addition, race and immigrant status does impact youth employment even after controlling for a full set of characteristics. This might be due to some form of demand-side racespecific hiring preferences in the urban labor market, and/or some unobserved human capital and skill set differentials among these groups on the supply side that are not perfectly captured by the variables present in this model. 
In order to explore the interaction of space and race, a series of race-specific and immigrant-specific probit models are estimated. Table 6 displays the regression results of three model specifications - model 1 includes only the spatial variables, model 2 includes all of the individual and household control variables, and model 3 adds the job accessibility variables to model 2 . In the first model, being in the central city has negative effect for all groups, but this effect is only statistically significant for white, Latino and both immigrant groups. The geographic effect is especially large for white youth. Interestingly, being in the central city does not have statistically significant effect for Black and Asian youth, two groups that have the lowest employment rate. The finding for Black youth is similar to some other finding for black youth during the 1980s in the Bay Area (Raphael 1998a) and across largest metropolitan areas in the United States (Holloway 1996) ${ }^{13}$, and might be due to the some non-geographic factors in the labor market that affect black youth across geography. This may be a partial explanation for the lack of impact of geography on Asian youth, but it could also be related to the fact that Asian youth have the highest enrollment rate in school. Finally, both first and second generation immigrants are adversely affected by location in the central city and inner ring suburbs.

Once the individual and household controls are included, the set of spatial coefficients are generally weaker in magnitude, but there are a few interesting differences from model 1. First, the coefficients on space for first-generation immigrants become insignificant, perhaps suggesting that first generation immigrants are more likely to follow the jobs than are native born households. Next, the coefficient on inner city

\footnotetext{
${ }^{13}$ Holloway (1996) found that the impact of job accessibility on employment probabilities declined between 1980 and 1990, especially for black male youth. This led the author to conclude that "[this group] is losing the advantage of accessibility rather than overcoming the disadvantage of inaccessibility" (p. 445)
} 
suburbs for Latinos and for second generation immigrants turns positive. However, after the job accessibility variables are included (model 3), this finding is reversed. This suggests that the job accessibility variables may be the mechanism by which space impacts immigrant status. After the job accessibility variables are included, the only coefficients that are significant are the central city coefficient for whites, and the inner ring suburb coefficient for Latinos and second generation immigrants. In results not shown, we estimated separate models for Asian and Latino immigrants. After including all of the household and job accessibility variables, there remains no impact of space for any Asian group. The negative impact of living in the inner ring suburbs is confined to native born Latinos and second generation immigrants. These results suggest that for new immigrants, residential and job mobility of the newcomers might offset their other obstacles in the labor market and explain their employment outcomes' relative insensitivity to location.

\section{$\underline{\text { Bivariate probit model for employment and school attendance }}$}

Finally, we estimate a bivariate probit model for employment and school attendance (Table 7). The estimates for employment are remarkably similar to those in Table 5. After controlling for the decision to attend school, there appears to be a similar impact of race and space on employment. While native born Latinos are as likely as whites to work (Table 7: model 3), Asians, blacks, and first and second generation immigrants are less likely to work. As before, there is a lower probability of being employment in the central city and inner ring suburbs.

The estimates of the school attendance regressions suggest that space also play a role in the likely of a youth attending school. Residence in the central city or the inner 
suburbs increases the likelihood of attending school. Among racial and immigrant groups, Asians and first and second generation immigrants are more likely than whites to be in school, while Latinos are less likely to be in school. Black youth are as likely as whites to be in school after controlling for other factors. This suggests that for these groups school attendance may be taking the place of work. On the other hand, black youth are not attending school at higher rates than are whites, despite being much less likely to be employed.

\section{CONCLUSION AND DISCUSSION}

The results presented in this paper suggest that both space and job accessibility continued to play a role in the employment outcomes of youth in the Los Angeles CMSA. Unlike some past analyses of Los Angeles for the 1980s, this paper focuses on youth because we can assume that their parents exogenously determine their location. In the areas of the central city and the inner ring suburbs, where jobs losses were significant during the decade of the 1990s, youth were less likely to be employed. Further emphasizing the issue of the manufacturing and service job losses were the significance of the change of jobs in these sectors on employment probabilities.

While other research has also found that race plays a role in employment outcomes, this paper has highlighted the different impacts of status as a first or second generation immigrant. This research suggests that both groups are likely to experience lower employment probabilities, but that native born, Latino children of foreign born parents are as likely to work as are white youth. This distinction places focus on the groups that are experiencing the worst employment outcomes. This analysis also tested 
for the interaction of space and race, and for the most part found few interacted effects. In stratified models of race and immigrant status, white youth in the central city and Latino and second generation immigrants in the inner ring suburbs experienced a deficit in employment. The fact that first generation immigrants were not influenced by space suggests that newer immigrants may be more mobile and therefore space does not create any further employment barriers.

The final set of analyses in this paper controlled for the likelihood that a youth will attend school simultaneously with the likelihood that the y will work in a bivariate probit framework. Importantly, the results for the role of race and space do not change after the addition of the equation measuring the likelihood of attending school. At the same time, the estimates in the school equation suggests that for Asian and first and second generation immigrant youth, attending school may be taking the place of work. In addition, youth are more likely to go to school in the regions that experience the largest job losses in services and manufacturing. This suggests that youth may be turning to education in places where job losses exist, but future research is needed to better understand this dynamic. 


\section{References:}

Aponte, Robert. 1996. Urban Employment and the Mismatch Dilemma: Accounting for the Immigration Exception. Social Problems 43 (3):268-283.

Borjas, G. J. 2001. Does immigration grease the wheels of the labor market? Brookings Papers on Economic Activity (1):69-133.

Brennan, J., and E. W. Hill. 1999. Where are the jobs? Cities, suburbs, and the competition for employment. The Brookings Institution, Center on Urban and Metropolitan Policy.

DeRango, K. 2001. Can commutes be used to test the spatial mismatch hypothesis? Urban Studies 38 (9): 1521-1529.

Downs, A. 1997. The challenge of our declining big cities. Housing Policy Debate 8 (2): 359-408.

Ellis, M., and R. Wright. 1999. The industrial division of labor among immigrants and internal migrants to the Los Angeles economy. International Migration Review 33 (1): $26-54$.

Ellwood, D. T. 1986. The spatial mismatch hypothesis: Are there teenage jobs missing in the ghetto? The Black Youth Employment Crisis. R. B. Freeman and H. Holzer. Chicago, University of Chicago Press, 147-185.

Frey, W. H. 2002. Census 2000 reveals new native-born and foreign-born shifts across U.S.: Ann Arbor, MI, Population Studies Center at the Institute for Social Research, University of Michigan.

Giuliano, G., and K. A. Small. 1991. Subcenters in the Los Angeles Region. Regional Science and Urban Economics 21 (2): 163-182.

Giuliano, G., Redfearn, C. 2005. Not all sprawl: Evolution of employment centers in Los Angeles, 1980-2000. Lusk Center for Real Estate Working Paper 2005-1002, University of Southern California.

Gordon, P., A. Kumar and H.W. Richardson. 1989. The spatial mismatch hypothesis: some new evidence. Urban Studies 26 (?): 315-326.

Greene, W. H. Econometric Analysis, $5^{\text {th }}$ ed. Upper Saddle River, New Jersey: Prentice Hall.

Holloway, S. R. 1996. Job accessibility and male teenage employment, 1980-1990: The declining significance of space? Professional Geographer 48 (4): 445-458. 
Holzer, H. J. 1991. The Spatial mismatch hypothesis: What has the evidence shown? Urban Studies 28(1): 105-122.

Ihlanfeldt, K. R. 1993. Intraurban Job Accessibility and Hispanic Youth Employment Rates. Journal of Urban Economics 33 (2):254-271.

Ihlanfeldt, K. R. and D. L. Sjoquist. 1998. The spatial mismatch hypothesis: a review of recent studies and their implications for welfare reform. Housing Policy Debate 9(4): 849-892.

Ihlanfeldt, K., and D. L. Sjoquist. 1990. Job accessibility and racial differences in youth employment rates. The American Economic Review 80 (1): 267-276.

Jencks, C. S. and S. E. Mayer. 1990. Residential segregation, job proximity, and black job opportunities. In Inner-City Poverty in the United States, edited by L. L. Jr. and M. McGeary. Washington, D.C.: National Academy Press.

Kain, J. F. 1968. Housing segregation, Negro employment, and metropolitan decentralization. Quarterly Journal of Economics 82: 157-197.

Kain, J. F. 1992. The spatial mismatch hypothesis: three decades later. Housing Policy Debate 3(2): 371-459.

McConville, S., and P. Ong. 2003. The trajectory of poor neighborhoods in Southern California, 1970-2000. The Brookings Institution, Center on Urban and Metropolitan Policy.

Myers, D., and C. Y. Liu. 2005. The emerging dominance of immigrants in the United States housing market, 1970-2000. Urban Policy and Research 23 (3): 347 - 365.

Myers, D., J. Pitkin and J. Park. 2005. "California Demographic Futures: Projections to 2030, by Immigrant Generations, Nativity, and Time of Arrival in U.S.” 2005 summary report, University of Southern California.

Ong, P. and D. Miller. 2005. Spatial and transportation mismatch in Los Angeles. Journal of Planning Education and Research 25 (1): 43-56.

O’Regan, K. M., and J. M. Quigley. 1991. Labor-market access and labor-market outcomes for urban youth. Regional Science and Urban Economics 21 (2): 277293.

O'Regan, K. M., and J. M. Quigley. 1998. Where youth live: Economic effects of urban space on employment prospects. Urban Studies 35 (7):1187-1205. 
Painter, G., S. A. Gabriel, and D. Myers. 2001. Race, immigrant status and housing tenure choice. Journal of Urban Economics 49 (1): 159-167.

Parks, V. 2004a. Access to work: the effects of spatial and social accessibility on unemployment for native-born black and immigrant women in Los Angeles. Economic Geography 80 (2): 141-172.

Parks, V. 2004b. The gendered connection between ethnic residential and labor-market segregation in Los Angeles. Urban Geography 25 (7): 589-630.

Pastor, M. 2001. Looking for regionalism in all the wrong places: demography, geography, and community in Los Angeles County. Urban Affairs Review 36 (6): 747-782.

Pastor, M., and E. Marcelli. 2000. Social, spatial and skill mismatch among immigrants and native-born workers in Los Angeles. Center for Comparative Immigration Studies Working Paper, University of California - San Diego No. 1.

Portes, A., and M. Zhou. 1993. The New 2nd-Generation - Segmented Assimilation and Its Variants. Annals of the American Academy of Political and Social Science 530:74-96.

Preston, V. and S. McLafferty. 1999. "Spatial mismatch research in the 1990s: progress and potential." Papers in Regional Science 78(4): 387-402.

Preston, V., S. McLafferty, and X. F. Liu. 1998. Geographical barriers to employment for American-born and immigrant workers. Urban Studies 35 (3):529-545.

Raphael, S. 1998a. Inter- and intra-ethnic comparisons of the central city - suburban youth employment differential: evidence from the Oakland Metropolitan Area. Industrial and Labor Relations Review 51 (3): 505-524.

Raphael, S. 1998b. The spatial mismatch hypothesis and black youth joblessness: Evidence from the San Francisco Bay Area. Journal of Urban Economics 43 (1): 79-111.

Raphael, S. and M. Stoll. 2001. "Can boosting minority car-ownership rates narrow interracial employment gaps?” Brookings-Wharton Papers on Urban Affairs 2001(1): 99-145.

Ross, S. L. 1998. Racial differences in residential and job mobility: Evidence concerning the spatial mismatch hypothesis. Journal of Urban Economics 43 (1):112-135.

Stoll, M. A. 1999a. Race, Space and Youth Labor Markets. Edited by S. Bruchey, Garland Studies in The History of American Labor. New York \& London: Garland Publishing. 
Stoll, M. A. 1999b. Spatial job search, spatial mismatch, and the employment and wages of racial and ethnic groups in Los Angeles. Journal of Urban Economics 46(1), 129-155.

Stoll, M. A. 1999c. Spatial mismatch, discrimination, and male youth employment in the Washington, DC area: Implications for residential mobility policies. Journal of Policy Analysis and Management 18 (1):77-98.

Stoll, M. A. 2005. Geographical skills mismatch, job search and race. Urban Studies 42 (4): 695-717.

Stoll, M. A. and S. Raphael. 2000. Racial differences in spatial job search patterns: exploring the causes and consequences. Economic Geography 76 (3): 201-231.

Stoll, M. A., E. Melendez, and A. Valenzuela. 2002. Spatial job search and job competition among immigrant and native groups in Los Angeles. Regional Studies 36 (2):97-112.

Stoll, M. A., H. J. Holzer and K. R. Ihlanfeldt. 2000. Within cities and suburbs: racial residential concentration and the spatial distribution of employment opportunities across sub- metropolitan areas. Journal of Policy Analysis and Management 19 (2): 207-231.

Taylor, B. and P. Ong. 1995. Spatial mismatch or automobile mismatch? An examination of race, residence and commuting in US metropolitan areas. Urban Studies 32 (9): 1453-1473.

Wilson, K. L. and A. Portes. 1980. "Immigrant Enclaves: An Analysis of the Labor Market Experiences of Cubans in Miami." American Journal of Sociology 86 (2): 295-319.

Zhou, M. 1997. Segmented assimilation: Issues, controversies, and recent research on the new second generation. International Migration Review 31 (4):975-1008.

Zhou, M. 2001. Progress, Decline, Stagnation? The New Second Generation Comes of Age. In Strangers at the Gates: New Immigrants in Urban America, edited by R. Waldinger. Berkeley and Los Angeles: University of California Press. 
Figure 1. Los Angeles CMSA Counties and LA City by PUMA

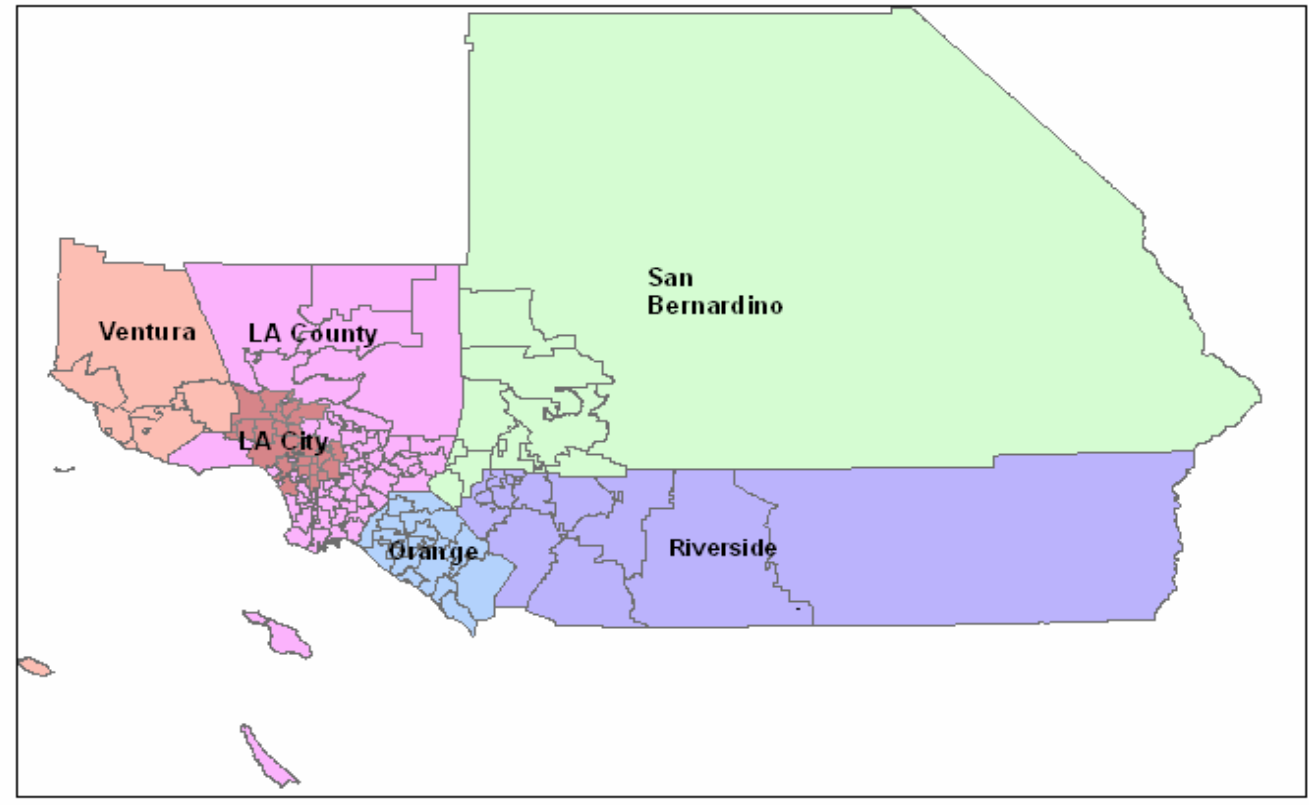


Figure 2. Geographic Areas of Los Angeles CMSA by PUMA 1990 and 2000
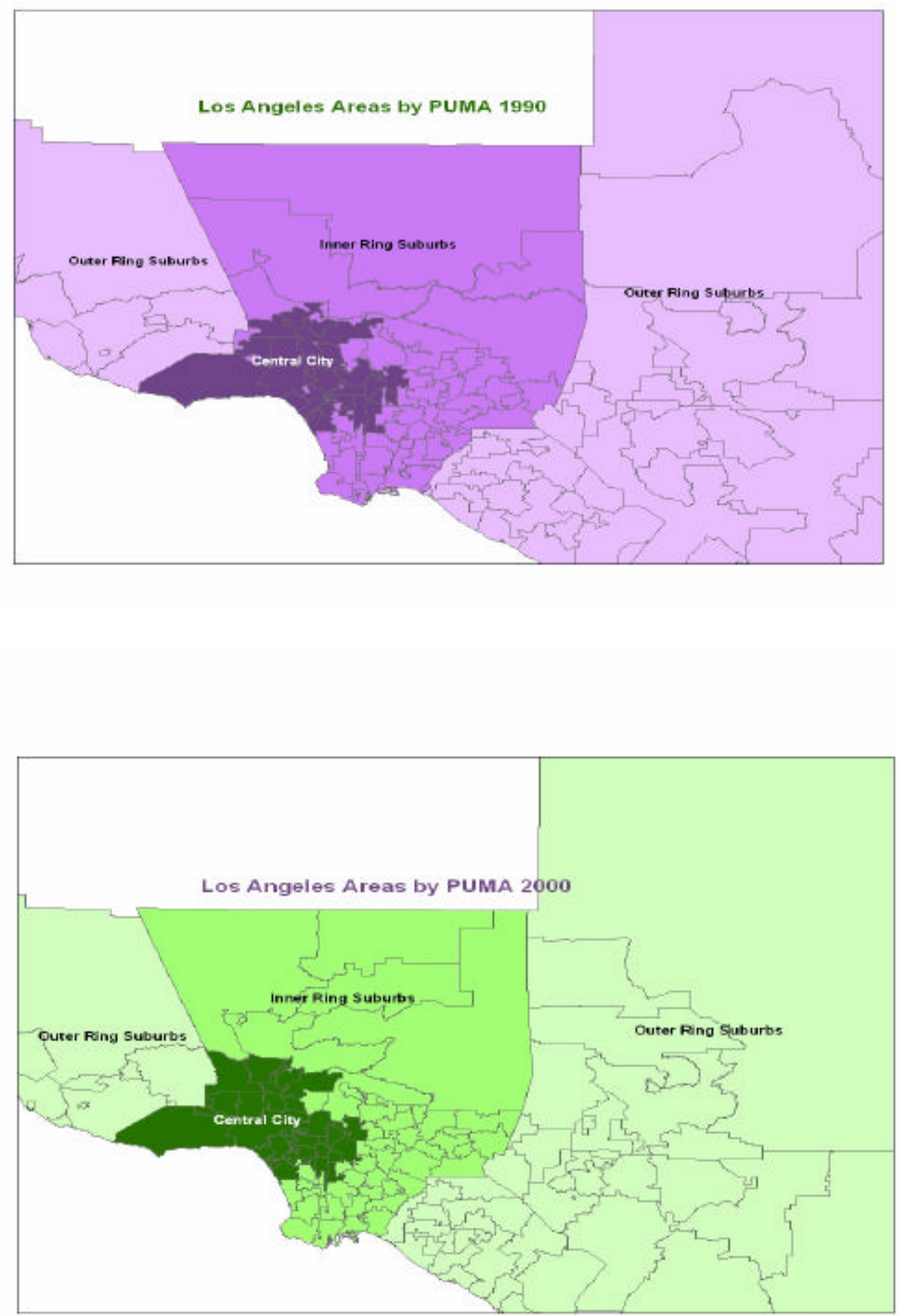
Table 1.

Population and Employment (by sector) Levels and Change by Area, 1990-2000

\begin{tabular}{|c|c|c|c|c|}
\hline & \multicolumn{4}{|c|}{ Central City } \\
\hline & 1990 level & 2000 level & Level Change & $\%$ Change \\
\hline Total Population & $3,820,693$ & $4,057,398$ & 236,705 & $6.2 \%$ \\
\hline Total Employment & $2,274,350$ & $2,160,033$ & $-114,317$ & $-5.0 \%$ \\
\hline Agriculture, Mining and Construction & 83,332 & 67,961 & $-15,371$ & $-18.4 \%$ \\
\hline Manufacturing & 366,086 & 259,672 & $-106,414$ & $-29.1 \%$ \\
\hline Wholesale and Retail Trade & 259,496 & 261,325 & 1,829 & $0.7 \%$ \\
\hline Services & 187,047 & 139,774 & $-47,273$ & $-25.3 \%$ \\
\hline Finance, Insurance and Real Estate & 917,674 & 933,780 & 16,106 & $1.8 \%$ \\
\hline \multirow[t]{3}{*}{ Combined $^{*}$} & 460,715 & 497,521 & 36,806 & $8.0 \%$ \\
\hline & \multicolumn{4}{|c|}{ Inner-Ring Suburbs } \\
\hline & 1990 level & 2000 level & Level Change & $\%$ Change \\
\hline Total Population & $5,042,479$ & $5,522,700$ & 480,221 & $9.5 \%$ \\
\hline Total Employment & $2,341,274$ & $2,293,085$ & $-48,189$ & $-2.1 \%$ \\
\hline Agriculture, Mining and Construction & 122,745 & 110,927 & $-11,818$ & $-9.6 \%$ \\
\hline Manufacturing & 523,589 & 396,717 & $-126,872$ & $-24.2 \%$ \\
\hline Wholesale and Retail Trade & 294,437 & 314,817 & 20,380 & $6.9 \%$ \\
\hline Services & 134,025 & 126,450 & $-7,575$ & $-5.7 \%$ \\
\hline Finance, Insurance and Real Estate & 739,535 & 784,685 & 45,150 & $6.1 \%$ \\
\hline \multirow[t]{3}{*}{ Combined $^{*}$} & 526,943 & 559,489 & 32,546 & $6.2 \%$ \\
\hline & \multicolumn{4}{|c|}{ Outer-Ring Suburbs } \\
\hline & 1990 level & 2000 level & Level Change & $\%$ Change \\
\hline Total Population & $5,668,361$ & $6,903,206$ & $1,234,845$ & $21.8 \%$ \\
\hline Total Employment & $2,402,778$ & $2,972,918$ & 570,140 & $23.7 \%$ \\
\hline Agriculture, Mining and Construction & 212,241 & 284,732 & 72,491 & $34.2 \%$ \\
\hline Manufacturing & 368,916 & 410,522 & 41,606 & $11.3 \%$ \\
\hline Wholesale and Retail Trade & 229,769 & 306,553 & 76,784 & $33.4 \%$ \\
\hline Services & 157,611 & 173,631 & 16,020 & $10.2 \%$ \\
\hline Finance, Insurance and Real Estate & 840,974 & $1,010,892$ & 169,918 & $20.2 \%$ \\
\hline Combined $^{*}$ & 593,267 & 786,588 & 193,321 & $32.6 \%$ \\
\hline
\end{tabular}

The data are aggregated from census tract-level employment data by SIC (Standard Industry Code) from the Southern California Association of Governments (SCAG).

${ }^{*}$ Combined category includes transportation, communications, other public utilities and public administration. 
Table 2.

Employment Rate and Activity Rate for Youths 16-21 by Area and Race/Ethnicity, 2000

\begin{tabular}{|c|c|c|c|c|c|c|c|c|c|c|c|}
\hline \multirow[b]{3}{*}{ AREA } & \multicolumn{11}{|c|}{ RACE/ETHNICITY } \\
\hline & \multirow{2}{*}{$\begin{array}{c}\text { White } \\
\text { All }\end{array}$} & \multirow{2}{*}{$\begin{array}{c}\text { Black } \\
\text { All }\end{array}$} & \multicolumn{4}{|c|}{ Asian } & \multicolumn{4}{|c|}{ Latino } & \multirow{2}{*}{ Total } \\
\hline & & & All & $\mathrm{FB}^{*}$ & $\mathrm{NB}-\mathrm{FP}^{* *}$ & NB-NP ${ }^{* * *}$ & All & $\mathrm{FB}^{*}$ & NB-FP** & NB-NP*** & \\
\hline \multicolumn{12}{|l|}{ Central City } \\
\hline Employment Rate & 0.33 & 0.23 & 0.24 & 0.26 & 0.21 & 0.36 & 0.31 & 0.31 & 0.32 & 0.33 & 0.30 \\
\hline Activity Rate & 0.94 & 0.86 & 0.95 & 0.94 & 0.97 & 0.95 & 0.87 & 0.84 & 0.90 & 0.88 & 0.90 \\
\hline $\mathbf{N}$ & 2023 & 1019 & 881 & 432 & 390 & 59 & 5083 & 1909 & 2701 & 473 & 9164 \\
\hline \multicolumn{12}{|l|}{ Inner-Ring Suburbs } \\
\hline Employment Rate & 0.42 & 0.24 & 0.24 & 0.24 & 0.21 & 0.36 & 0.33 & 0.33 & 0.33 & 0.36 & 0.33 \\
\hline Activity Rate & 0.94 & 0.85 & 0.97 & 0.96 & 0.98 & 0.94 & 0.88 & 0.84 & 0.89 & 0.88 & 0.91 \\
\hline $\mathbf{N}$ & 3507 & 1200 & 2260 & 1025 & 1048 & 187 & 7936 & 1874 & 4336 & 1726 & 15317 \\
\hline \multicolumn{12}{|l|}{ Outer-Ring Suburbs } \\
\hline Employment Rate & 0.44 & 0.27 & 0.28 & 0.25 & 0.27 & 0.42 & 0.38 & 0.36 & 0.37 & 0.41 & 0.39 \\
\hline Activity Rate & 0.94 & 0.88 & 0.97 & 0.97 & 0.97 & 0.94 & 0.88 & 0.84 & 0.89 & 0.90 & 0.91 \\
\hline $\mathbf{N}$ & 7556 & 897 & 1830 & 798 & 862 & 170 & 6991 & 1901 & 3036 & 2054 & 17690 \\
\hline \multicolumn{12}{|l|}{ Total } \\
\hline Employment Rate & 0.42 & 0.25 & 0.25 & 0.25 & 0.23 & 0.38 & 0.34 & 0.33 & 0.34 & 0.38 & 0.35 \\
\hline Activity Rate & 0.94 & 0.86 & 0.96 & 0.96 & 0.97 & 0.94 & 0.88 & 0.84 & 0.89 & 0.89 & 0.91 \\
\hline $\mathbf{N}$ & 13086 & 3116 & 4971 & 2255 & 2300 & 416 & 20010 & 5684 & 10073 & 4253 & 42171 \\
\hline
\end{tabular}

The sample is drawn from the 2000 Census PUMS 5\% datafiles. The sample includes all at-home youth aged 16 to 21 with no post-high school degrees and no work disabilities

${ }^{*}$ FB indicates youth who are foreign-born, i.e. first-generation immigrants.

${ }^{* *}$ NB-FP indicates youth who are native-born, but at least one of the parents are foreign-born, i.e. second-generation immigrants.

${ }^{* * *}$ NB-NP indicates youth who are native-born, with native-born parents. 
Table 3.

Means of Personal, Household and Family Variables by Area, 2000

\begin{tabular}{|c|c|c|c|c|}
\hline Variables & All & $\begin{array}{c}\text { Central } \\
\text { City }\end{array}$ & $\begin{array}{c}\text { Inner-Ring } \\
\text { Suburbs }\end{array}$ & $\begin{array}{l}\text { Outer-Ring } \\
\text { Suburbs }\end{array}$ \\
\hline Employment Rate & 0.35 & 0.30 & 0.33 & 0.39 \\
\hline Activity Rate & 0.91 & 0.90 & 0.91 & 0.91 \\
\hline \multicolumn{5}{|l|}{ Personal Variables } \\
\hline Age & 18.01 & 18.04 & 18.03 & 17.97 \\
\hline Female & 0.48 & 0.49 & 0.47 & 0.48 \\
\hline With Child & 0.03 & 0.03 & 0.03 & 0.03 \\
\hline Poverty & 0.14 & 0.21 & 0.15 & 0.10 \\
\hline In School & 0.80 & 0.79 & 0.80 & 0.80 \\
\hline High School Graduate & 0.18 & 0.17 & 0.18 & 0.18 \\
\hline Some College & 0.20 & 0.19 & 0.21 & 0.20 \\
\hline White & 0.31 & 0.22 & 0.23 & 0.43 \\
\hline Black & 0.07 & 0.11 & 0.08 & 0.05 \\
\hline Asian & 0.12 & 0.10 & 0.15 & 0.10 \\
\hline Latino & 0.47 & 0.55 & 0.52 & 0.40 \\
\hline Immigrant (first generation) & 0.22 & 0.32 & 0.22 & 0.17 \\
\hline Immigrant (second generation) & 0.35 & 0.40 & 0.40 & 0.27 \\
\hline \multicolumn{5}{|l|}{ Household Variables } \\
\hline Household Size & 5.20 & 5.27 & 5.28 & 5.09 \\
\hline Household Worker & 2.53 & 2.39 & 2.50 & 2.63 \\
\hline Youth Worker & 0.73 & 0.64 & 0.71 & 0.80 \\
\hline Homeownership & 0.60 & 0.47 & 0.60 & 0.68 \\
\hline Car & 0.93 & 0.87 & 0.93 & 0.95 \\
\hline Household Income & $\$ 74,780$ & $\$ 68,076$ & $\$ 70,919$ & $\$ 81,596$ \\
\hline \multicolumn{5}{|l|}{ Family Variables } \\
\hline Parent Weeks Worked 1999 & 43.89 & 41.44 & 43.48 & 45.53 \\
\hline Parent High School Graduate & 0.16 & 0.14 & 0.17 & 0.16 \\
\hline Parent Some College & 0.21 & 0.16 & 0.20 & 0.25 \\
\hline Parent College Graduate & 0.32 & 0.28 & 0.30 & 0.36 \\
\hline Two-Parent Family & 0.71 & 0.66 & 0.71 & 0.74 \\
\hline $\mathbf{N}$ & 42,171 & 9,164 & 15,317 & 17,690 \\
\hline
\end{tabular}

The sample is drawn from the 2000 Census PUMS 5\% datafiles. The sample includes all at-home youth aged 16 to 21 with no post-high school degrees and no work disabilities. 
Table 4.

Means of Personal, Household and Family Variables by Race/Ethnicity, 2000

\begin{tabular}{|c|c|c|c|c|}
\hline Variables & White & Black & Asian & Latino \\
\hline Employment Rate & 0.42 & 0.25 & 0.25 & 0.34 \\
\hline Activity Rate & 0.94 & 0.86 & 0.96 & 0.88 \\
\hline \multicolumn{5}{|l|}{ Personal Variables } \\
\hline Central City & 0.15 & 0.33 & 0.18 & 0.25 \\
\hline Inner-Ring Suburbs & 0.27 & 0.39 & 0.45 & 0.40 \\
\hline Outer-Ring Suburbs & 0.58 & 0.29 & 0.37 & 0.35 \\
\hline Age & 17.91 & 17.95 & 18.03 & 18.08 \\
\hline Female & 0.47 & 0.50 & 0.47 & 0.48 \\
\hline With Child & 0.01 & 0.04 & 0.01 & 0.05 \\
\hline Poverty & 0.06 & 0.22 & 0.12 & 0.19 \\
\hline In School & 0.84 & 0.78 & 0.93 & 0.74 \\
\hline High School Graduate & 0.17 & 0.18 & 0.15 & 0.19 \\
\hline Some College & 0.23 & 0.19 & 0.28 & 0.16 \\
\hline Immigrant (first generation) & 0.07 & 0.04 & 0.45 & 0.28 \\
\hline Immigrant (second generation) & 0.13 & 0.07 & 0.46 & 0.50 \\
\hline \multicolumn{5}{|l|}{ Household Variables } \\
\hline Household Size & 4.32 & 4.68 & 4.74 & 5.97 \\
\hline Household Worker & 2.49 & 1.96 & 2.38 & 2.69 \\
\hline Youth Worker & 0.79 & 0.54 & 0.56 & 0.76 \\
\hline Homeownership & 0.75 & 0.42 & 0.64 & 0.53 \\
\hline Car & 0.98 & 0.87 & 0.96 & 0.90 \\
\hline Household Income & $\$ 101,647$ & $\$ 56,959$ & $\$ 76,774$ & $\$ 59,843$ \\
\hline \multicolumn{5}{|l|}{ Family Variables } \\
\hline Parent Weeks Worked 1999 & 46.98 & 38.16 & 44.78 & 42.79 \\
\hline Parent High School Graduate & 0.14 & 0.21 & 0.11 & 0.18 \\
\hline Parent Some College & 0.28 & 0.34 & 0.16 & 0.16 \\
\hline Parent College Graduate & 0.53 & 0.32 & 0.59 & 0.12 \\
\hline Two-Parent Family & 0.74 & 0.41 & 0.82 & 0.72 \\
\hline $\mathbf{N}$ & 13,086 & 3,116 & 4,971 & 20,010 \\
\hline
\end{tabular}

The sample is drawn from the 2000 Census PUMS 5\% datafiles. The sample includes all at-home youth aged 16 to 21 with no post-high school degrees and no work disabilities. 
Table 5.

Probit Regressions of Youth Employment Status

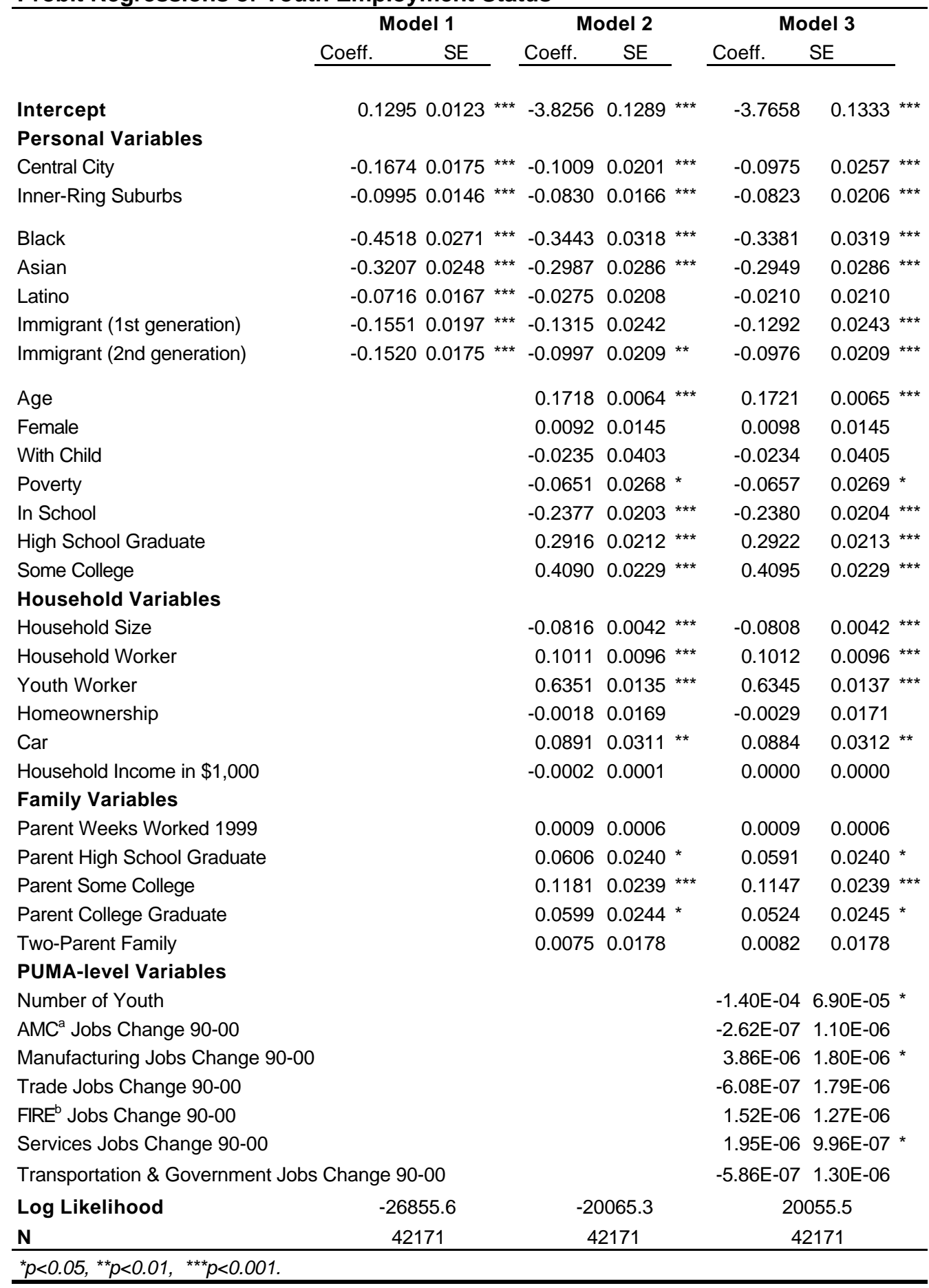

Notes:

a. AMC stands for Agriculture, Mining and Construction.

b. FIRE stands for Finance, Insurance and Real Estate. 
Table 6.

Probit Regressions of Youth Employment Status on Area Indicators by Race/Ethnicity and Immigrant-Specific Models

\begin{tabular}{|c|c|c|c|c|c|c|c|c|c|c|c|c|c|c|}
\hline & & \multicolumn{2}{|c|}{ White } & \multicolumn{3}{|c|}{ Black } & \multicolumn{2}{|c|}{ Asian } & \multicolumn{2}{|c|}{ Latino } & \multicolumn{2}{|c|}{$\begin{array}{l}\text { 1st generation } \\
\text { Immigrant }\end{array}$} & \multicolumn{2}{|c|}{$\begin{array}{l}\text { 2st generation } \\
\text { Immigrant }\end{array}$} \\
\hline & & Coefficient & SE & & Coefficient & SE & Coefficient & SE & Coefficient & SE & Coefficient & SE & Coefficient & SE \\
\hline \multirow{2}{*}{ Model 1} & Central City & -0.3175 & 0.0323 & $* * *$ & -0.1130 & 0.0625 & -0.1050 & 0.0557 & -0.1727 & 0.0239 *** & -0.0868 & 0.0341 * & -0.1530 & 0.0286 *** \\
\hline & Inner-Ring Suburbs & -0.0718 & 0.0258 & $* *$ & -0.0686 & 0.0599 & -0.1271 & 0.0426 ** & -0.1177 & $0.0211^{* * *}$ & -0.0760 & 0.0327 * & -0.1190 & $0.0251^{* * *}$ \\
\hline \multirow{2}{*}{ Model 2} & Central City & -0.2390 & 0.0370 & $* * *$ & -0.0713 & 0.0739 & -0.1180 & 0.0653 & -0.0672 & 0.0279 * & -0.0115 & 0.0394 & -0.0844 & $0.0331 *$ \\
\hline & Inner-Ring Suburbs & -0.0686 & 0.0292 & * & -0.0082 & 0.0697 & -0.0980 & 0.0498 * & 0.0899 & $0.0241^{* * *}$ & -0.0204 & 0.0374 & 0.1028 & $0.0287^{* * \star}$ \\
\hline \multirow{2}{*}{ Model 3} & Central City & -0.1753 & 0.0485 & $\star \star \star *$ & -0.1778 & 0.1034 & -0.1342 & 0.0848 & -0.0682 & 0.0374 & -0.0335 & 0.0533 & -0.0712 & 0.0450 \\
\hline & Inner-Ring Suburbs & -0.0611 & 0.0342 & & -0.1017 & 0.0985 & -0.1018 & 0.0640 & -0.0686 & $0.0321 *$ & -0.0118 & 0.0479 & -0.0925 & 0.0375 * \\
\hline & $\mathbf{N}$ & \multicolumn{2}{|c|}{13086} & \multicolumn{3}{|c|}{3116} & \multicolumn{2}{|c|}{4971} & \multicolumn{2}{|c|}{20010} & \multicolumn{2}{|c|}{9232} & \multicolumn{2}{|c|}{14579} \\
\hline
\end{tabular}

${ }^{*} p<0.05,{ }^{* *} p<0.01,{ }^{* * *} p<0.001$.

Model 1 above regress employment status only on area dummy variables (central city and inner-ring suburbs) with no other control variables.

Model 2 above regress emplloyment status on area indicators plus a vector of personal, household, and family variables (as specified in table 3 without race/ethnicity and immigrant status variables - Black, Asian, Latino, 1st generation immigrant and 2nd generation immigrant)

Model 3 above regress employment status on area indicators pulus a vector of personal, household, and family variables and labor supply and job accessibility measures on PUMA level (as specified in table 3 without race/ethnicity and immigrant status variables). 


\begin{tabular}{|c|c|c|c|c|c|c|c|c|c|c|c|c|c|c|c|c|c|}
\hline & \multicolumn{5}{|c|}{ Model 1} & \multicolumn{6}{|c|}{ Model 2} & \multicolumn{6}{|c|}{ Model 3} \\
\hline & \multicolumn{3}{|c|}{ Employment } & \multicolumn{2}{|c|}{ In School } & \multicolumn{3}{|c|}{ Employment } & \multicolumn{2}{|c|}{ In School } & & \multicolumn{3}{|c|}{ Employment } & \multicolumn{3}{|c|}{ In School } \\
\hline & Coeff. & SE & & Coeff. & SE & Coeff. & SE & & Coeff. & SE & & Coeff. & SE & & Coeff. & SE & \\
\hline Intercept & -0.1295 & 0.0123 & $* * *$ & 0.9553 & $0.0144^{* \star *}$ & -4.5248 & 0.1141 & $* * *$ & 9.6998 & 0.1321 & $* \star *$ & -4.4644 & 0.1189 * & $* * *$ & 9.6600 & 0.1379 * & *** \\
\hline \multicolumn{18}{|l|}{ Personal Variables } \\
\hline Central City & -0.1674 & 0.0175 & $* \star *$ & 0.0549 & $0.0193^{* *}$ & -0.1060 & 0.0200 & $* * *$ & 0.1061 & 0.0232 & 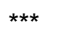 & -0.1013 & 0.0257 * & $* * *$ & 0.0790 & 0.0299 * & $\star *$ \\
\hline Black & -0.4483 & 0.0270 & $* * *$ & -0.2108 & $0.0285^{* * *}$ & -0.3427 & 0.0317 & $* * *$ & -0.0052 & 0.0353 & & -0.3369 & 0.0319 * & $* * *$ & 0.0061 & 0.0355 & \\
\hline Asian & -0.3206 & 0.0248 & 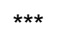 & 0.4311 & $0.0320^{* *}$ & -0.3158 & 0.0285 & $* \star \star$ & 0.4468 & 0.0386 & 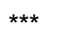 & -0.3121 & 0.0286 * & 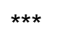 & 0.4491 & 0.0387 * & $* \star *$ \\
\hline Latino & -0.0721 & 0.0167 & $* * *$ & -0.4030 & $0.0189 * *$ & -0.0206 & 0.0208 & & -0.1286 & 0.0246 & *** & -0.0146 & 0.0210 & & -0.1169 & 0.0249 * & $* \star *$ \\
\hline Immigrant (1st generation & -0.1552 & 0.0197 & $* \star *$ & -0.0704 & $0.0215^{* *}$ & -0.1411 & 0.0241 & $* \star *$ & 0.1942 & 0.0278 & *** & -0.1384 & 0.0243 * & $* * *$ & 0.1841 & 0.0280 * & $* \star *$ \\
\hline Immigrant (2nd generatiol & -0.1523 & 0.0175 & $* * *$ & 0.1591 & 0.0196 ** & -0.1107 & 0.0208 & $* * *$ & 0.2239 & 0.0249 & $* * *$ & -0.1084 & 0.0209 * & $* * *$ & 0.2176 & $0.0250 *$ & $* * *$ \\
\hline Age & & & & & & 0.2021 & 0.0059 & $* * *$ & -0.5081 & 0.0069 & 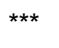 & 0.2025 & 0.0059 * & $* * *$ & -0.5082 & $0.0069 *$ & $* * *$ \\
\hline Female & & & & & & -0.0003 & 0.0145 & & 0.1896 & 0.0171 & $\star * \star$ & 0.0002 & 0.0145 & & 0.1904 & $0.0171 *$ & $* * *$ \\
\hline Poverty & & & & & & -0.0612 & 0.0267 & * & -0.0912 & 0.0283 & ** & -0.0619 & 0.0268 * & * & -0.0897 & 0.0283 * & ** \\
\hline High School Graduate & & & & & & 0.3141 & 0.0210 & $* * *$ & -0.3761 & 0.0219 & 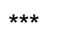 & 0.3147 & 0.0210 * & 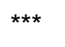 & -0.3765 & 0.0219 * & $* * *$ \\
\hline Some College & & & & & & 0.3437 & 0.0222 & $* * *$ & 0.8833 & 0.0266 & 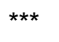 & 0.3442 & 0.0222 * & 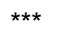 & 0.8817 & 0.0266 * & $* \star *$ \\
\hline \multicolumn{18}{|l|}{ Household Variables } \\
\hline Household Size & & & & & & -0.0793 & 0.0042 & $* * *$ & -0.0284 & 0.0045 & $* * *$ & -0.0786 & 0.0042 * & $* * *$ & -0.0277 & $0.0045 *$ & $* * *$ \\
\hline Household Worker & & & & & & 0.1004 & 0.0095 & $* * *$ & 0.0005 & 0.0107 & & 0.1004 & 0.0095 * & $* * *$ & 0.0002 & 0.0107 & \\
\hline Youth Worker & & & & & & 0.6385 & 0.0135 & ${ }^{* * *}$ & -0.1242 & 0.0153 & 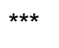 & 0.6380 & $0.0135 *$ & $* * *$ & -0.1245 & 0.0153 * & $* * *$ \\
\hline Homeownership & & & & & & -0.0096 & 0.0169 & & 0.1533 & 0.0193 & $\star \star \star *$ & -0.0110 & 0.0170 & & 0.1590 & $0.0195 *$ & $* * *$ \\
\hline Car & & & & & & 0.0806 & 0.0309 & ** & 0.1236 & 0.0316 & $* * *$ & 0.0799 & 0.0310 * & ** & 0.1238 & 0.0316 * & $* * *$ \\
\hline Household Income in $\$ 1,00$ & & & & & & $-2 \mathrm{E}-07$ & $1.2 \mathrm{E}-07$ & & $4 \mathrm{E}-07$ & $2 \mathrm{E}-07$ & * & $-2.3 \mathrm{E}-07$ & $1.2 \mathrm{E}-07$ & & 3.34E-07 & $1.61 \mathrm{E}-07$ * & * \\
\hline Parent Weeks Worked 199s & & & & & & 0.0009 & 0.0006 & & 0.001 & 0.001 & & 0.0009 & 0.0006 & & 0.0007 & 0.001 & \\
\hline Parent High School Gradua & uate & & & & & 0.0566 & 0.0239 & * & 0.057 & 0.026 & * & 0.0551 & 0.0239 * & * & 0.0581 & $0.026 *$ & * \\
\hline Parent Some College & & & & & & 0.1076 & 0.0238 & $3^{* * *}$ & 0.156 & 0.027 & 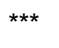 & 0.1042 & 0.0239 * & $* * *$ & 0.1551 & $0.027 *$ & $* * *$ \\
\hline Parent College Graduate & & & & & & 0.0401 & 0.0243 & & 0.389 & 0.029 & *** & 0.0329 & 0.0244 & & 0.3842 & $0.029 *$ & $* \star *$ \\
\hline Two-Parent Family & & & & & & 0.0012 & 0.0178 & & 0.111 & 0.020 & 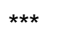 & 0.0019 & 0.0178 & & 0.1118 & $0.020 *$ & 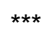 \\
\hline AMC $^{a}$ Jobs Change 90-00 & & & & & & & & & & & & $-1.30 \mathrm{E}-07$ & $1.09 \mathrm{E}-06$ & & $-3.1 E-06$ & 1.3E-06 * & \\
\hline Manufacturing Jobs Chang & ige $90-00$ & & & & & & & & & & & 3.78E-06 & $1.80 \mathrm{E}-06$ * & & $1.89 \mathrm{E}-06$ & 2.16E-06 & \\
\hline
\end{tabular}


Trade Jobs Change 90-00

FIRE ${ }^{b}$ Jobs Change 90-00

Services Jobs Change 90-00

Transportation \& Government Jobs Change 90-00
Log Likelihood
$-46579$

_rho

N

${ }^{*} p<0.05,{ }^{* *} p<0.01,{ }^{* * *} p<0.001$

Notes:

a. AMC stands for Agriculture, Mining and Construction.

b. FIRE stands for Finance, Insurance and Real Estate.
$-3.39 \mathrm{E}-07$ 1.78E-06

1.55E-06 1.27E-06

1.93E-06 9.95E-07

$-6.10 \mathrm{E}-07$ 1.30E-06

$-34355$

42171
$-6.4 \mathrm{E}-06 \quad 2.11 \mathrm{E}-06$ **

$-5.1 \mathrm{E}-07 \quad 1.53 \mathrm{E}-06$

4.73E-07 1.22E-06

$1.11 \mathrm{E}-06 \quad 1.54 \mathrm{E}-06$

42171 
Appendix A

Table A.1.

Definition of Independent Variables

\begin{tabular}{|c|c|}
\hline \multicolumn{2}{|l|}{ Personal Variables } \\
\hline Central City & Residence in Central City ( $1=$ yes) \\
\hline Inner-Ring Suburbs & Residence in Inner-Ring Suburbs ( $1=$ yes) \\
\hline Outer-Ring Suburbs & Residence in Outer-Ring Suburbs ( $1=$ yes) \\
\hline White & Youth is Non-Hispanic White ( $1=$ yes) \\
\hline Black & Youth is Non-Hispanic Black ( $1=$ yes) \\
\hline Asian & Youth is Non-Hispanic Asian ( $1=$ yes) \\
\hline Latino & Youth is Hispanic $(1=$ yes $)$ \\
\hline Immigrant (1st generation) & Youth is foreign-born $(1=$ yes $)$ \\
\hline Immigrant (2nd generation) & Youth is native-born with at least one foreign-born parent $(1=$ yes \\
\hline Age & Age of youth in years $(18-21)$ \\
\hline Female & Gender of youth ( 1 = female) \\
\hline With Child & Youth has child $(1=$ yes $)$ \\
\hline Poverty & Youth under poverty line ( 1 = yes) \\
\hline In School & Youth enrolled in school ( $1=$ yes $)$ \\
\hline High School Graduate & Youth has high school degree $(1=$ yes $)$ \\
\hline Some College & Youth has some college education ( $1=$ yes $)$ \\
\hline
\end{tabular}

\section{Household Variables}

Household Size

Household Worker

Youth Worker

Homeownership

Car

Household Income in $\$ 1,000$
Number of household members (excluding non-relatives)

Number of people who worked in 1999

Number of people aged 18-21 who worked in 1999

Housing tenure $(1=$ own $)$

Presence of automobile(s) in household (1=yes)

Total household income in dollar amount / 1,000

\section{Family Variables}

Parent Weeks Worked 1999* Number of weeks worked 1999

Parent High School Graduate* Parent has high school degree $(1=$ yes $)$

Parent Some College ${ }^{\star} \quad$ Parent has some college education $(1=$ yes $)$

Parent College Graduate* Parent has college degree or higher ( $1=$ yes)

Two-Parent Family Youth lives in two-parent household $(1=$ yes)

Labor Market Variables

Labor Supply

Number of comparable youth per PUMA

Job Growth

Number of Job Change $90-00$ by 6 industry groups per PUMA

* Parent work and education variables represent the higher values of the two parents, if in a twoparent family. 